Article

\title{
Influence of Attitudes toward Violence and Motor Impulsiveness on the Violent Behavior of Adolescents at School
}

\author{
David Pina ${ }^{1}{ }^{(\mathbb{D}}$, José Jiménez-Barbero ${ }^{1} \mathbb{1}$, Cecília Calero-Mora ${ }^{2}$, Esteban Puente-Lopez ${ }^{1, * \mathbb{C}}$, \\ José António Ruiz-Hernández ${ }^{1}$, Inmaculada Galián-Muñoz ${ }^{2}$, Laura Llor-Zaragoza ${ }^{1}$ and Maria Vidal-Alves ${ }^{3,4} \mathbb{D}$
}

Citation: Pina, D.; Jiménez-Barbero, J.; Calero-Mora, C.; Puente-Lopez, E.; Ruiz-Hernández, J.A.; Galián-Muñoz, I.; Llor-Zaragoza, L.; Vidal-Alves, M. Influence of Attitudes toward Violence and Motor Impulsiveness on the Violent Behavior of Adolescents at School. Forensic Sci. 2022, 2,

253-261. https://doi.org/ $10.3390 /$ forensicsci2010019

Academic Editor: Ricardo Dinis-Oliveira

Received: 13 August 2021 Accepted: 25 February 2022

Published: 2 March 2022

Publisher's Note: MDPI stays neutral with regard to jurisdictional claims in published maps and institutional affiliations.

Copyright: (C) 2022 by the authors. Licensee MDPI, Basel, Switzerland. This article is an open access article distributed under the terms and conditions of the Creative Commons Attribution (CC BY) license (https:// creativecommons.org/licenses/by/ $4.0 /)$.
1 Applied Psychology Service, University of Murcia, 30100 Murcia, Spain; david.pina@um.es (D.P.); joseantonio.jimenez1@um.es (J.J.-B.); jaruiz@um.es (J.A.R.-H.); laura.llor@um.es (L.L.-Z.)

2 Administration of the National Institute of Social Security (INSS), Ministry of Work, Migration and Social Security, 30001 Murcia, Spain; cecilya87@gmail.com (C.C.-M.); inmaculada.galian@carm.es (I.G.-M.)

3 Department of Public Health and Forensic Sciences, and Medical Education, Faculty of Medicine of University of Porto, 4200-319 Porto, Portugal; mjalves@med.up.pt

4 EPI Unit, Faculty of Medicine, University of Porto, 4200-319 Porto, Portugal

* Correspondence: esteban.puente@um.es; Tel.: +34-678-52-5481

\begin{abstract}
Background: School violence during adolescence has become a major issue worldwide. Both impulsiveness and adolescents' attitudes toward violence will influence violent behavior against peers at school. Our objective is to study the influence of motor impulsiveness and attitudes on adolescents' violent behavior at school, as well as to assess sex and age differences. Methods: Cluster sampling was performed, obtaining a sample of 513 adolescents between 13 and 19 years from four centers of secondary education. Results: A strong relationship is found between violent school behavior, defined as relational and overt aggression, and attitudes towards violence perceived as legitimate defense and violence used to cope with problems and social relations. The results showed significant sex differences favoring the boys in all the variables studied, except for motor impulsiveness and relational aggression. In terms of age, we found significant differences only for motor impulsiveness, favoring the older age group ( $\geq 15$ years). The current findings may provide an important core of evidence to support forensic decision making in pre-trial and court settings, and further contribute to recidivism prevention.
\end{abstract}

Keywords: school violence; attitudes toward violence; motor impulsiveness; violent behavior; adolescents

\section{Introduction}

Violence in adolescents has become a major challenge in recent decades, especially with regard to school violence. This is a worldwide problem, which can be seen in any kind of school, and has led to fear, truancy, or even the suicide of the victim. The prevalence of students involved in violent episodes varies between 20 and 30\%, or even reaches $50 \%$, depending on the studies [1-4]. These percentage differences must be interpreted cautiously, considering the definition of school violence used, among other factors. This study assumes the definition of school violence of UNESCO (2019), which defines it as any violent physical (attacks, fights, corporal punishment), psychological (verbal abuse, emotional abuse, social exclusion), or sexual act (completed and attempted non-consensual sex acts, unwanted touching, sexual harassment).

Violent behavior directed toward others is associated with genetic, neurobiological, and psychophysiological factors and is a serious threat with deleterious consequences both individually and socially [5]. Different distinctions have been made concerning violent behavior. It can be direct or overt, including physical or verbal behavior directed at an individual, and indirect or relational, with the purpose of disrupting the other person's circle of friends or their perception of belonging to a group [6]. While direct violence is more visible, indirect violence is harder to observe [7]. 
Early (10-14 years) and late adolescence (15-19 years) are of great concern [8], and school violence reaches its peak in early adolescence, between the ages of 11 and 13 [9].

Adolescence is when many physical, psychological, and behavioral changes take place and risky behaviors related to externalizing behavioral disorders increase. The same happens with impulsiveness, which is one of the most typical features of this phase and, along with sensation-seeking, is highly related to immature prefrontal cortex [10-15]. Eysenck (1993) defined impulsiveness as the tendency to act without prior reflexive process, despite the consequences, possibly due to inhibitory deficits. This decreases with age, when the prefrontal cortex matures [16]. It is a multi-faceted personality construct, with a possible genetic or environmental basis $[17,18]$. Impulsiveness may run in three dimensions: unplanned, or without careful planning; motor impulsiveness, described as a predisposition to act instinctively or the inability to withhold responses; and cognitive, related to the inability to focus [19]. Various authors indicate impulsiveness as a predecessor of violent conduct. It is usually associated with male individuals, which may be due to neuro-endocrine dissimilarities or to different paths in social learning [20,21]. There is also evidence that adolescents tend to carry out more impulsive behaviors amid peers, and that impulsiveness may enable a transition from attitudes that are favorable toward violence to actual violent behavior [11,22].

Adolescents' beliefs and attitudes towards violence (ATV) are deemed risk factors for violent behavior [23,24]. Attitudes arise from various personal, social, or family factors and lead to a series of beliefs under the influence of which adolescents engage in violent behaviors to improve their self-esteem, have fun, solve social problems, or self-defend $[25,26]$.

Multiple investigations of children's ATV have been done in recent decades [27-29]. However, even though school violence arises from the family, school, and community context axis [30], no consensual model combines the variables that influence school violence in adolescents [31].

This study follows the classical theoretical models of which advocate for the importance of attitudes as a tendency to act non-deliberately and/or impulsively. This attitudebehavior connection is seen in violence in adolescents, predominantly violence which is impulsive rather than premeditated [32,33].

Although the above-mentioned literature relates ATV and impulsiveness to school violence, it seems worthwhile to examine the relationship between these variables in greater depth. The goals of this study are to determine the degree of association among impulsiveness, ATV, and violent behavior, as well as the possible significant sex and age differences, and to develop a predictive model that allows the determination of which factors have a greater influence on students' development of violent behavior.

\section{Experimental Section}

\subsection{Participants}

The sample was collected from four secondary education schools, and participants were aged between 13 and 19 years. Adolescents who had special educational needs were excluded from the study. Of the 580 potential students, 69 (36 boys and 33 girls) were eliminated by the exclusion criteria mentioned in Section 2.4 (Data Analysis). The final sample is made up of 511 participants: 255 boys (49.7\%), 245 girls (47.8\%), and 11 with this information missing. The mean age is 14.793 years $(S D=1.293)$. Table 1 shows the main sociodemographic variables of the study along with their valid percentages. 
Table 1. Sociodemographic variables.

\begin{tabular}{|c|c|c|}
\hline Variables & $n$ & $(\%)$ \\
\hline \multicolumn{3}{|l|}{ Age } \\
\hline$\leq 14$ & 276 & $(53.8)$ \\
\hline$\geq 15$ & 236 & $(45.9)$ \\
\hline Missing & 1 & $(0.2)$ \\
\hline \multicolumn{3}{|l|}{ Sex } \\
\hline Boys & 255 & $(49.7)$ \\
\hline Girls & 245 & $(47.8)$ \\
\hline Missing & 13 & $(2.5)$ \\
\hline \multicolumn{3}{|l|}{ Father's educational level } \\
\hline No studies & 54 & $(10.5)$ \\
\hline Primary education & 238 & $(46.4)$ \\
\hline Secondary education & 128 & $(25.0)$ \\
\hline Upper education & 73 & $(14.2)$ \\
\hline Missing & 20 & $(3.9)$ \\
\hline \multicolumn{3}{|l|}{ Mother's educational level } \\
\hline No studies & 51 & $(9.9)$ \\
\hline Primary education & 212 & $(41.3)$ \\
\hline Secondary education & 121 & $(23.6)$ \\
\hline Upper education & 113 & $(22.0)$ \\
\hline Missing & 16 & $(3.1)$ \\
\hline \multicolumn{3}{|l|}{ With whom do you live? } \\
\hline I live with both my parents & 393 & $(76.6)$ \\
\hline I don't live with both my parents & 107 & $(20.9)$ \\
\hline Missing & 13 & $(2.5)$ \\
\hline \multicolumn{3}{|l|}{ Final term grade } \\
\hline Failed & 105 & $(20.5)$ \\
\hline Passed & 108 & $(21.1)$ \\
\hline Good & 124 & $(24.2)$ \\
\hline Notable & 120 & $(23.4)$ \\
\hline Outstanding & 40 & $(7.8)$ \\
\hline Missing & 16 & (3.1) \\
\hline \multicolumn{3}{|l|}{ Nationality } \\
\hline European & 430 & $(83.8)$ \\
\hline Other & 71 & $(13.8)$ \\
\hline Missing & 12 & $(2.3)$ \\
\hline
\end{tabular}

\subsection{Materials}

In addition to the sociodemographic variables used for the description of the sample, we used the scales of motor impulsiveness, attitudes toward violence, and violent behavior at school.

We used the Barratt Impulsiveness Scale [19], which divides impulsiveness into three dimensions, motor impulsiveness, unplanned impulsiveness, and cognitive impulsiveness, in its validated Spanish version [34], which has a good level of internal consistency (Cronbach's $\alpha=0.90$ [21]; Cronbach's $\alpha=0.78$ in our sample). We only used the motor subscale of the instrument due to its relevance to the goals of the study.

We used the "Cuestionario de Actitudes hacia la Violencia" (CAHV-28; in English, the Questionnaire of Attitudes toward Violence) [33]. This instrument has four factors: ATV as a form of fun (seven items, Cronbach's $\alpha=0.80$ in our sample), ATV to improve self-esteem (seven items, Cronbach's $\alpha=0.85$ in our sample), ATV to cope with problems and social relations (seven items, Cronbach's $\alpha=0.78$ in our sample), and ATV perceived as legitimate defense (seven items, Cronbach's $\alpha=0.81$ in our sample). The level of internal consistency for the total scale was of Cronbach's $\alpha=0.90$.

We used the scale of Violent Behavior at School [6], specifically the LISIS team's adapted version of the scale [35]. This is a 25-item self-administered questionnaire with a response range of $1-4$, which rates two kinds of violent behavior: overt aggression and 
relational or indirect aggression. In our sample, the internal consistency was Cronbach's $\alpha=0.80$ and 0.70 , respectively. The level of internal consistency for the total scale was Cronbach's $\alpha=0.83$.

Self-reported questionnaires usually produce bias related to social desirability, which is especially prevalent in adolescents [21]. To reduce the limitation of this bias associated with self-reports, we included the Social Desirability scale of the "Cuestionario de AutoControl Infantil y Adolescente" (CACIA; in English, the Children and Adolescent Self-Control Questionnaire) [36], which is considered appropriate to control for this error since it has only 14 items and is short, simple, and easily understandable. In addition, the CACIA questionnaire is complemented with a self-informed sincerity question to avoid youngsters' propensity to provide responses that are socially desirable, as far as possible [37]. Responders may position their answers from "Totally sincere" to "I've lied a lot.".

\subsection{Procedure and Design}

The present sample follows a cross-sectional design and followed the STROBE criteria with a sample of adolescents from four secondary education schools during the years 2015 and 2016. The schools, located in the Region of Murcia, Spain, were selected through random cluster sampling, assuming a confidence level of $95 \%$ and a level of error of $3 \%$, taking into account the public and semi-public schools. We first obtained a list of all schools in the locality where the study was conducted. Subsequently, all schools were invited to participate. Among those schools that decided to participate, the questionnaire was administered to all children. The protocol used included a 97-item questionnaire, which was completed by the adolescents in the classroom and then enclosed in a sealed envelope.

The study was devised in accord with the Declaration of Helsinki (World Medical Association, 2013) and the proposals of the American Psychological Association (APA) and obtained approval of the Ethics and Clinical Research Committee. We obtained the consent of participants and their parents. Information on the study was provided, ensuring confidentiality and anonymity in the treatment of the data and giving participants the chance to refuse to participate. Only one student refused to participate.

\subsection{Data Analysis}

We used the SPSS 22.0 statistical package to analyze the data. Questionnaires with high scores on the Social Desirability scale according to the scale norms were excluded from the analysis. No differences were found in sociodemographic variables between the study sample and the excluded group.

To evaluate the sex and age differences in the variables, we carried out Student's $t$-test. Pearson correlation analysis was performed to establish the association between the different variables. Lastly, we carried out step-wise multiple linear regression analysis in order to develop a predictive model of school violence. The level of significance was defined as $p \leq 0.05$.

\section{Results}

The comparison of boys' and girls' means showed significant differences in all the variables studied, except for motor impulsiveness and relational aggression, for which no significant differences were found, as depicted in Table 2.

In terms of age, we found significant differences only for motor impulsiveness $(t=2.699$, $p=0.007$ ) for the older age group ( $\geq 15$ years vs. $<15$ years), but no differences for various types of violence or factors of attitudes towards violence.

As can be seen in Table 3, we obtained positive correlations between overt aggression and all the factors of ATV (range $=0.470-0.589, p<0.01$ ), as well as with the variable motor impulsiveness $(r=0.165, p<0.001)$. Relational aggression also obtained a positive correlation with all the factors of ATV (range $=0.406-0.454, p<0.001$ ) and with motor impulsiveness $(r=0.217, p<0.001)$. 
Table 2. Student's $t$-test analysis of the study variables according to sex.

\begin{tabular}{|c|c|c|c|c|c|}
\hline Variables & Sex & $M$ & $S D$ & $t$ & $d$ \\
\hline \multirow[t]{2}{*}{ Motor impulsiveness } & Boys & 16.235 & 5.318 & 1.068 & 0.095 \\
\hline & Girls & 15.726 & 5.334 & & \\
\hline \multirow[t]{2}{*}{ ATV Fun } & Boys & 2.098 & 0.792 & $3.860^{* * *}$ & 0.346 \\
\hline & Girls & 1.853 & 0.613 & & \\
\hline \multirow{2}{*}{ ATV Self-esteem } & Boys & 1.729 & 0.731 & $4.383^{* * *}$ & 0.392 \\
\hline & Girls & 1.479 & 0.528 & & \\
\hline \multirow[t]{2}{*}{ ATV Social skills } & Boys & 1.968 & 0.744 & $4.526^{* * *}$ & 0.405 \\
\hline & Girls & 1.696 & 0.588 & & \\
\hline \multirow[t]{2}{*}{ ATV Legitimate } & Boys & 2.979 & 0.906 & $5.748^{* * *}$ & 0.726 \\
\hline & Girls & 2.355 & 0.808 & & \\
\hline \multirow[t]{2}{*}{ Overt aggression } & Boys & 18.516 & 5.607 & $5.319^{* * *}$ & 0.477 \\
\hline & Girls & 16.286 & 3.482 & & \\
\hline \multirow[t]{2}{*}{ Relational aggression } & Boys & 18.978 & 4.744 & 1.381 & 0.123 \\
\hline & Girls & 18.425 & 4.182 & & \\
\hline
\end{tabular}

Note: $\mathrm{ATV}=$ Attitudes towards violence; $d=$ Cohen's $\mathrm{d},{ }^{* * *} p<0.001$.

Table 3. P Correlations between various factors of aggressiveness, and its predictive variables.

\begin{tabular}{|c|c|c|c|c|c|}
\hline & \multirow{2}{*}{$\begin{array}{c}\text { Motor } \\
\text { Impulsiveness }\end{array}$} & \multicolumn{4}{|c|}{ Attitudes Towards Violence } \\
\hline & & Fun & Self-Esteem & Social Skills & Legitimate \\
\hline $\begin{array}{c}\text { Overt } \\
\text { aggression }\end{array}$ & $0.165^{* * *}$ & $0.470 * * *$ & $0.546^{* * *}$ & $0.589^{* * *}$ & $0.544^{* * *}$ \\
\hline $\begin{array}{l}\text { Relational } \\
\text { aggression }\end{array}$ & $0.217^{* * *}$ & $0.406^{* * *}$ & $0.454^{* * *}$ & $0.448^{* * *}$ & $0.435^{* * *}$ \\
\hline
\end{tabular}

Variables that had shown significant correlations after calculating the Pearson correlation were included in the linear regression analysis. The regression model presented in Table 4 shows the results achieved for each of the factors enclosed in the variable aggressiveness, adjusted for sex.

Table 4. Linear regression model of overt and relational aggressiveness.

\begin{tabular}{|c|c|c|c|c|c|c|c|c|c|}
\hline & & \multirow[t]{2}{*}{ Predictor Variables } & \multicolumn{4}{|c|}{ Regression Coefficients } & \multicolumn{2}{|c|}{$\begin{array}{l}\text { Fit of the } \\
\text { Model }\end{array}$} & \multirow{2}{*}{$\begin{array}{c}\text { ANOVA } \\
F\end{array}$} \\
\hline & & & $B$ & $S E$ & $B$ & $t$ & $R$ & $R^{2}$ & \\
\hline \multirow{7}{*}{$\begin{array}{c}\text { Overt } \\
\text { Aggressiveness }\end{array}$} & \multirow[t]{4}{*}{ Boys } & Constant & 7.508 & 0.912 & & $8.236^{* * *}$ & 0.644 & 0.415 & $59.374^{* * *}$ \\
\hline & & ATV Social skill & 2.101 & 0.658 & 0.279 & $3.195 * *$ & & & \\
\hline & & ATV Legitimate & 1.398 & 0.391 & 0.226 & $3.573^{* * *}$ & & & \\
\hline & & ATV Self-esteem & 1.713 & 0.620 & 0.223 & $2.765^{* *}$ & & & \\
\hline & \multirow[t]{3}{*}{ Girls } & Constant & 10.004 & 0.618 & & $16.176^{* * *}$ & 0.565 & 0.319 & $56.602 * * *$ \\
\hline & & ATV Legitimate & 1.355 & 0.300 & 0.314 & $4.518^{* * *}$ & & & \\
\hline & & ATV Social skills & 1.822 & 0.412 & 0.308 & $4.421^{* * *}$ & & & \\
\hline \multirow{7}{*}{$\begin{array}{c}\text { Relational } \\
\text { Aggressiveness }\end{array}$} & Boys & Constant & 11.949 & 0.865 & & $13.812 * * *$ & 0.497 & 0.247 & $41.391^{* * *}$ \\
\hline & \multirow{6}{*}{ Girls } & ATV Self-esteem & 2.217 & 0.428 & 0.342 & $5.186^{* * *}$ & & & \\
\hline & & ATV Legitimate & 1.142 & 0.345 & 0.218 & $3.312 * *$ & & & \\
\hline & & Constant & 10.098 & 0.935 & & 10.796 & 0.536 & 0.287 & $32.334 * * *$ \\
\hline & & ATV Social skills & 1.964 & 0.509 & 0.276 & $3.856^{* * *}$ & & & \\
\hline & & ATV Legitimate & 1.359 & 0.370 & 0.263 & $3.668^{* * *}$ & & & \\
\hline & & Motor impulsiveness & 0.114 & 0.043 & 0.146 & $2.630 * *$ & & & \\
\hline
\end{tabular}




\subsection{Overt Aggression}

In girls, overt aggressive was associated with the ATV perceived as legitimate defense $(\beta=0.314, p=0.000)$ and the attitude towards violence to cope with problems and social relations $(\beta=0.308, p=0.000)$. The fit of the model was moderate $\left(R^{2}=0.319, p=0.000\right)$.

In boys, overt aggression was associated with the ATV to cope with problems and social relations $(\beta=0.279, p=0.002)$, the ATV perceived as legitimate defense $(\beta=0.226$, $p=0.000)$, and the ATV to improve self-esteem $(\beta=0.223, p=0.006)$. In this case, the fit of the model was higher, though also moderate $\left(R^{2}=0.415, p=0.000\right)$.

\subsection{Relational Aggression}

The linear regression model for girls only explained $28.7 \%$ of the variance (adjusted $R^{2}=0.287, p=0.000$ ). In this case, besides the association with the ATV to cope with problems and social relations $(\beta=0.276, p=0.000)$ and the ATV perceived as legitimate defense $(\beta=0.263, p=0.000)$, there was also an association with motor impulsiveness $(\beta=0.146, p=0.009)$. In the case of boys, the fit of the model was slightly lower (adjusted $\left.R^{2}=0.247, p=0.000\right)$ and only included the ATV to improve self-esteem $(\beta=0.342, p=0.000)$ and the ATV perceived as legitimate defense $(\beta=0.218, p=0.001)$.

\section{Discussion}

This study has met the proposed objectives. On the one hand, this study reveals the influence of adolescents' ATV and motor impulsiveness in school violence, both overt and relational. On the other hand, the relationship is explored according to gender and age, developing a predictive model.

The analysis shows no significant age differences in most of the studied variables, except for motor impulsiveness, where we found higher levels in the older group of the sample. Other studies claim that impulsiveness refines during the transition from childhood to adolescence or stabilizes throughout development [38]. The results from the present study may have been affected by the circumstance that the older group is made up of students whose ages do not correspond to their grade, and therefore they may be experiencing academic failure, which has been linked to high levels of impulsiveness [39,40].

Another perspective, though, presents evidence that academic obstacles, such as perceived meaninglessness by adolescents, may trigger impulsiveness as a response to boredom [41] In fact, the combination of impulsivity along with sensation-seeking and susceptibility to boredom has been considered as a predictor of violence engagement at school [42-44].

Secondly, we found sex differences in favor of boys for all attitudes favoring violent behavior, as well as for the overt aggressiveness variable. In this sense, boys are considered to be more violent and tend to express more direct violence than girls [31]. The differences found may be related to the fact that girls are seen as more empathetic and better able to share victims' emotions and discomfort [7], or to the different parenting style for girls and boys, which is still maintained [21,45]. Others authors have found no sex differences in ATV [24].

Thirdly, regarding the predictive model presented in our results, we find that the ATV perceived as a legitimate defense, that is, justifying school violence as legitimate in the face of grievances or injustice, it is related to both overt and relational aggressiveness. This may be because violent children tend to believe that aggression is a legitimate and acceptable behavior, as well as a suitable way to deal with offenses and minimize their consequences, eventually normalizing it (McMahon et al., 2013). The ATV to cope with problems and social relationships also appears as an important predictor of aggressiveness, especially in girls. In this sense, violence can be used as a means to attempt to improve one's social status. Some adolescents expect to have a gain from the use of violence, such as peer acceptance, which leads them to minimize the harm caused and to justify violence, in order to thrive socially $[31,46]$. 
A noteworthy aspect of our results is that the ATV to improve self-esteem is only present in boys to justify violence but is not used by girls. In some studies, it has been reported that children who are violent at school have low levels of self-esteem [47]. Good levels of self-esteem are crucial for adolescents' self-confidence. The factors influencing self-esteem in the formation of boys' identities are different from those present in girls. Due to gender stereotypes, it is possible that boys feel, sense, or expect that they must be violent to properly form their identity and be "good guys", so their self-esteem depends on this $[7,48]$.

Impulsive individuals may present an alteration in the production of moral judgments, and therefore of the consequences of their actions, which facilitates violent behavior, especially in individuals who have low inhibitory control [5,49]. However, not all impulsive individuals are violent or express violence in the same way [44]. Our study shows that motor impulsiveness is only related to relational aggression in girls, but not in boys. Girls have a greater capacity for self-control [50], and although girls are generally less violent, this relationship with motor impulsiveness could be a determining factor compared to boys, who tend to have higher impulsiveness scores [18].

In the long run, unattended impulsivity problems, allied to inhibition difficulties, are proven to precede criminal behavior, and this is commonly found in inmate samples, often as part of an antisocial profile [51], with a close relationship to the phenotypic facet of meanness [52]. The current findings may provide an important core of evidence to support forensic decision making in pre-trial and court settings and further contribute to recidivism prevention.

The design of this study has some limitations that must be taken into account when interpreting the results. On the one hand, this is a cross-sectional study, which precludes inferring relationships of causality between the variables. On the other hand, the study focuses on a specific geographical area; to control for this limitation, we conducted a study that included four schools with a random selection of the sample, carried out with cluster sampling. In addition, since this region has great economic diversity, the schools included individuals representing diverse socioeconomic strata.

Finally, we used self-administered questionnaires, a fact that hinders obtaining honest answers from adolescents; to prevent this limitation, we eliminated those cases that exceeded the required cut-off point in the Social Desirability scale and in the question related to sincerity.

\section{Conclusions}

The attitude towards violence perceived as legitimate defense and the attitude towards violence to cope with problems and social relations have the highest relation with violence, including either relational or overt aggressiveness. On the other hand, the attitude toward violence to improve self-esteem only predicts violence in males.

Regarding motor impulsiveness, our results indicate that this variable is related to violence, although the predictive model associates it particularly with relational aggression in girls.

In general, our findings recommend the need to investigate the efficacy of programs focused on the modification of these attitudes toward violence as a way to improve coexistence at school. They may further provide a pertinent core of evidence to support forensic decision making in pre-trial and court settings and contribute to recidivism prevention.

Author Contributions: Conceptualization, D.P., J.J.-B., J.A.R.-H. and I.G.-M.; data curation, C.C.-M. and L.L.-Z.; formal analysis, D.P. and E.P.-L.; investigation, C.C.-M. and M.V.-A.; resources, C.C.-M., L.L.-Z. and M.V.-A.; writing-original draft, D.P., E.P.-L. and M.V.-A.; writing-review and editing, J.J.-B. and J.A.R.-H. All authors have read and agreed to the published version of the manuscript.

Funding: This study was partly financed by an aid granted by the "Fundación para la Formación e Investigación Sanitarias" (Foundation for Training and Health Research) of the Region of Murcia (file number FFIS17/CE/01/13). 
Informed Consent Statement: Informed consent was obtained from all subjects involved in the study.

Data Availability Statement: Data presented in this manuscript are available upon request from the corresponding author.

Conflicts of Interest: The authors declare no conflict of interest.

\section{References}

1. Albayrak, S.; Yıldız, A.; Erol, S. Assessing the effect of school bullying prevention programs on reducing bullying. Child. Youth Serv. Rev. 2016, 63, 1-9. [CrossRef]

2. Craig, W.; Harel-Fisch, Y.; Fogel-Grinvald, H.; Dostaler, S.; Hetland, J.; Simons-Morton, B.; Due, P.; Molcho, M.; De Mato, M.G.; Overpeck, M. A cross-national profile of bullying and victimization among adolescents in 40 countries. Int. J. Public Health 2009, 54, 216-224. [CrossRef] [PubMed]

3. Leff, S.S.; Feudtner, C. Tackling bullying: Grounds for encouragement and sustained focus. Pediatrics 2017, 139 , e20170504. [CrossRef] [PubMed]

4. Wang, J.; Iannotti, R.J.; Nansel, T.R. School bullying among adolescents in the United States: Physical, verbal, relational, and cyber. J. Adolesc. Health 2009, 45, 368-375. [CrossRef] [PubMed]

5. Alcázar-Córcoles, M.Á.; Verdejo-Garcia, A.; Bouso-Saiz, J.C.; Bezos-Saldana, L. Neuropsychology of impulsive aggression. Rev. Neurol. 2010, 50, 291-299. [PubMed]

6. Little, T.D.; Henrich, C.C.; Jones, S.M.; Hawley, P.H. Disentangling the "whys" from the "whats" of aggressive behaviour. Int. J. Behav. Dev. 2003, 27, 122-133. [CrossRef]

7. Muñoz, L.C.; Qualter, P.; Padgett, G. Empathy and bullying: Exploring the influence of callous-unemotional traits. Child Psychiatry Hum. Dev. 2011, 42, 183-196. [CrossRef]

8. Santiesteban, T.B. Alcohol consumption in early adolescence and medical care. Arch. Argent. Pediatr. 2016, 114, $412-418$.

9. Jalón, M.J.D.-A. La violencia entre iguales en la adolescencia y su prevención desde la escuela. Psicothema 2005, 17, 549-558.

10. Álvarez García, D.; Núñez Pérez, J.C.; García Fernández, T.; Barreiro Collazo, A. Individual, family, and community predictors of cyber-aggression among adolescents. Eur. J. Psychol. Appl. Leg. Context 2018, 10, 79-88. [CrossRef]

11. Arain, M.; Haque, M.; Johal, L.; Mathur, P.; Nel, W.; Rais, A.; Sharma, S.; Sandhu, R. Maturation of the adolescent brain. Neuropsychiatr. Dis. Treat. 2013, 9, 449. [PubMed]

12. Casey, B.; Jones, R.M.; Somerville, L.H. Braking and accelerating of the adolescent brain. J. Res. Adolesc. 2011, 21, 21-33. [CrossRef] [PubMed]

13. Ho, S.M.; Dai, D.W.T.; Mak, C.; Liu, K.W.K. Cognitive factors associated with depression and anxiety in adolescents: A two-year longitudinal study. Int. J. Clin. Health Psychol. 2018, 18, 227-234. [CrossRef] [PubMed]

14. Knight, D.K.; Dansereau, D.F.; Becan, J.E.; Rowan, G.A.; Flynn, P.M. Effectiveness of a theoretically-based judgment and decision making intervention for adolescents. J. Youth Adolesc. 2015, 44, 1024-1038. [CrossRef]

15. Piko, B.F.; Varga, S.; Mellor, D. Are adolescents with high self-esteem protected from psychosomatic symptomatology? Eur. J. Pediatr. 2016, 175, 785-792. [CrossRef]

16. Raaijmakers, M.A.; Smidts, D.P.; Sergeant, J.A.; Maassen, G.H.; Posthumus, J.A.; Van Engeland, H.; Matthys, W. Executive functions in preschool children with aggressive behavior: Impairments in inhibitory control. J. Abnorm. Child Psychol. 2008, 36, 1097. [CrossRef]

17. Li, J.-B.; Willems, Y.E.; Stok, F.M.; Deković, M.; Bartels, M.; Finkenauer, C. Parenting and self-control across early to late adolescence: A three-level meta-analysis. Perspect. Psychol. Sci. 2019, 14, 967-1005. [CrossRef]

18. Niv, S.; Tuvblad, C.; Raine, A.; Wang, P.; Baker, L.A. Heritability and longitudinal stability of impulsivity in adolescence. Behav. Genet. 2012, 42, 378-392. [CrossRef]

19. Barratt, E.S. Impulsiveness subtraits: Arousal and information processing. Motiv. Emot. Personal. 1985, 99, 137-146.

20. Eisenberg, N.; Spinrad, T.L.; Fabes, R.A.; Reiser, M.; Cumberland, A.; Shepard, S.A.; Valiente, C.; Losoya, S.H.; Guthrie, I.K.; Thompson, M.; et al. The relations of effortful control and impulsivity to children's resiliency and adjustment. Child Dev. 2004, 75, 25-46. [CrossRef]

21. Jiménez-Barbero, J.A.; Ruiz-Hernández, J.A.; Llor-Esteban, B.; Waschgler, K. Influence of attitudes, impulsivity, and parental styles in adolescents' externalizing behavior. J. Health Psychol. 2016, 21, 122-131. [CrossRef] [PubMed]

22. Jiménez-Barbero, J.A.; Ruiz-Hernández, J.A.; Velandrino-Nicolás, A.P.; Llor-Zaragoza, L. Actitudes hacia la violencia, impulsividad, estilos parentales y conducta externalizada en adolescentes: Comparación entre una muestra de población general y una muestra clínica. An. Psicol. 2016, 32, 132-138. [CrossRef]

23. McMahon, S.D.; Todd, N.R.; Martinez, A.; Coker, C.; Sheu, C.-F.; Washburn, J.; Shah, S. Aggressive and prosocial behavior: Community violence, cognitive, and behavioral predictors among urban African American youth. Am. J. Community Psychol. 2013, 51, 407-421. [CrossRef]

24. Stoddard, S.A.; Varela, J.J.; Zimmerman, M.A. Future expectations, attitude towards violence, and bullying perpetration during early adolescence: A mediation evaluation. Nurs. Res. 2015, 64, 422. [CrossRef]

25. Cutrín, O.; Gómez-Fraguela, J.A.; Luengo, M.Á. Peer-group mediation in the relationship between family and juvenile antisocial behavior. Eur. J. Psychol. Appl. Leg. Context 2015, 7, 59-65. [CrossRef] 
26. Ruiz-Hernández, J.A.; Llor-Zaragoza, L.L.; Puebla, T.; Llor-Esteban, B. Evaluación de las actitudes hacia la violencia en el contexto educativo: El CAHV-25. In Mejora de la Convivencia y Programas Encaminados a la Prevención e Intervención del Acoso Escolar; Grupo Editorial Universitario: Granada, Spain, 2007.

27. Fox, C.L.; Elder, T.; Gater, J.; Johnson, E. The association between adolescents' beliefs in a just world and their attitudes to victims of bullying. Br. J. Educ. Psychol. 2010, 80, 183-198. [CrossRef]

28. Pina, D.; Llor-Esteban, B.; Ruiz-Hernández, J.A.; Luna-Maldonado, A.; Puente-López, E. Attitudes towards school violence: A qualitative study with Spanish children. J. Interpers. Violence 2021. [CrossRef]

29. Silke, C.; Brady, B.; Boylan, C.; Dolan, P. Factors influencing the development of empathy and pro-social behaviour among adolescents: A systematic review. Child. Youth Serv. Rev. 2018, 94, 421-436. [CrossRef]

30. Elsaesser, C.; Hong, J.S.; Voisin, D.R. Violence exposure and bullying among African American adolescents: Examining the protective role of academic engagement. Child. Youth Serv. Rev. 2016, 70, 394-402. [CrossRef]

31. Fives, C.J.; Kong, G.; Fuller, J.R.; DiGiuseppe, R. Anger, aggression, and irrational beliefs in adolescents. Cogn. Ther. Res. 2011, 35, 199-208. [CrossRef]

32. Jiménez-Barbero, J.A.; Ruiz-Hernández, J.A.; Llor-Esteban, B.; Llor-Zaragoza, L.; García, M.P. Efficacy of a brief intervention on attitudes to reduce school violence: A randomized clinical trial. Child. Youth Serv. Rev. 2013, 35, 1313-1318. [CrossRef]

33. Ruiz-Hernández, J.A.; Pina, D.; Puente-López, E.; Luna-Maldonado, A.; Llor-Esteban, B. Attitudes towards school violence questionnaire, revised version: CAHV-28. Eur. J. Psychol. Appl. Leg. Context 2020, 12, 61-68. [CrossRef]

34. Luengo, M.; Carrillo-De-La-Pena, M.; Otero, J. The components of impulsiveness: A comparison of the I.7 Impulsiveness Questionnaire and the Barratt Impulsiveness Scale. Personal. Individ. Differ. 1991, 12, 657-667. [CrossRef]

35. Cava, M.J.; Musitu, G.; Murgui, S. Familia y violencia escolar: El rol mediador de la autoestima y la actitud hacia la autoridad institucional. Psicothema 2006, 18, 367-373. [PubMed]

36. Capafóns-Bonet, A.; Moreno, S. Cuestionario de Auto-Control Infantil y Adolescente; España: Tea Ediciones: Madrid, Spain, 1998.

37. Miller, P.H.; Baxter, S.D.; Royer, J.A.; Hitchcock, D.B.; Smith, A.F.; Collins, K.L.; Guinn, C.H.; Smith, A.L.; Puryear, M.P.; Vaadi, K.K.; et al. Children's social desirability: Effects of test assessment mode. Personal. Individ. Differ. 2015, 83, 85-90. [CrossRef]

38. Bezdjian, S.; Tuvblad, C.; Wang, P.; Raine, A.; Baker, L.A. Motor impulsivity during childhood and adolescence: A longitudinal biometric analysis of the go/no-go task in 9- to 18-year-old twins. Dev. Psychol. 2014, 50, 2549. [CrossRef]

39. Colom, R.; Escorial, S.; Shih, P.C.; Privado, J. Fluid intelligence, memory span, and temperament difficulties predict academic performance of young adolescents. Personal. Individ. Differ. 2007, 42, 1503-1514. [CrossRef]

40. Gray, S.A.; Dueck, K.; Rogers, M.; Tannock, R. Qualitative review synthesis: The relationship between inattention and academic achievement. Educ. Res. 2017, 59, 17-35. [CrossRef]

41. Moynihan, A.B.; Igou, E.R.; Van Tilburg, W.A.P. Boredom increases impulsiveness: A meaning-regulation perspective. Social Psychology. 2017, 48, 293-309. [CrossRef]

42. Del Carmen Pérez-Fuentes, M.; Jurado, M.d.M.M.; Márquez, M.d.M.S.; Linares, J.J.G. Predictive capacity of drug use, impulsivity and sensation-seeking in aggressors and victims of violence. Preprints 2019, 2019030055. [CrossRef]

43. Molero Jurado, M.D.M.; Pérez-Fuentes, M.D.C.; Simón Márquez, M.D.M.; Barragán Martín, A.B.; Sisto, M.; Gázquez Linares, J.J. Relationship between impulsivity, sensation-seeking, and drug use in aggressors and victims of violence. Front. Psychol. 2020, 11, 2902. [CrossRef] [PubMed]

44. Pérez Fuentes, M.D.C.; Molero Jurado, M.d.M.; Carrión Martínez, J.J.; Mercader Rubio, I.; Gázquez, J.J. Sensation-seeking and impulsivity as predictors of reactive and proactive aggression in adolescents. Front. Psychol. 2016, 7, 1447. [CrossRef] [PubMed]

45. Cutrín, O.; Maneiro, L.; Sobral, J.; Gómez-Fraguela, J.A. Longitudinal effects of parenting mediated by deviant peers on violent and non-violent antisocial behaviour and substance use in adolescence. Eur. J. Psychol. Appl. Leg. Context 2018, 11, 23-32. [CrossRef]

46. Fanti, K.A. Individual, social, and behavioral factors associated with co-occurring conduct problems and callous-unemotional traits. J. Abnorm. Child Psychol. 2013, 41, 811-824. [CrossRef] [PubMed]

47. Tsaousis, I. The relationship of self-esteem to bullying perpetration and peer victimization among schoolchildren and adolescents: A meta-analytic review. Aggress. Violent Behav. 2016, 31, 186-199. [CrossRef]

48. Brito, C.C.; Oliveira, M.T. Bullying and self-esteem in adolescents from public schools. J. Pediatr. 2013, 89, 601-607. [CrossRef] [PubMed]

49. Sarkisian, K.; Van Hulle, C.; Lemery-Chalfant, K.; Goldsmith, H. Childhood inhibitory control and adolescent impulsivity and novelty seeking as differential predictors of relational and overt aggression. J. Res. Personal. 2017, 67, 144-150. [CrossRef]

50. Low, S.; Espelage, D. Conduits from community violence exposure to peer aggression and victimization: Contributions of parental monitoring, impulsivity, and deviancy. J. Couns. Psychol. 2014, 61, 221. [CrossRef]

51. Sellbom, M.; Phillips, T.R. An examination of the triarchic conceptualization of psychopathy in incarcerated and nonincarcerated samples. J. Abnorm. Psychol. 2013, 122, 208. [CrossRef]

52. Weidacker, K.; O’Farrell, K.R.; Gray, N.S.; Johnston, S.J.; Snowden, R.J. Psychopathy and impulsivity: The relationship of the triarchic model of psychopathy to different forms of impulsivity in offenders and community participants. Personal. Individ. Differ. 2017, 114, 134-139. [CrossRef] 